\title{
NEW RECORDS FOR AUSTRALIAN ALGAE
}

\author{
VALERIE MaY
}

(Accepted 2.12.1976)

\begin{abstract}
May, Valerie (National Herbarium of New South Wales, Royal Botanic Gardens, Sydney, Australia 2000) 1978. New Records for Australian Algae. Telopea 1 (5):315-318.--Records of the occurrence of a freshwater alga new to Australia [Diacanthos belenophorus (Chlorophyta)], of a marine alga new to Australia [Ceramium paniculatum (Rhodophyta)] and of certain marine algae new to New South Wales [Anotrichium tenue and Spyridia dasyoides (Rhodophyta) and Oscillatoria erythraea (Cyanophyta)] are reported. The occurrence in unusual circumstances or quantities of Ectocarpus (Phaeophyta) and of Anacystis cyanea and Nostoc sphaericum (Cyanophyta) is noted also. (Algal Systematics; Plant Distribution)
\end{abstract}

All specimens cited are held in the National Herbarium of New South Wales, Royal Botanic Gardens, Sydney, Australia (NSW).

\section{NEW RECORDS FOR AUSTRALIA}

\section{Diacanthos belenophorus Korchikoff Chlorophyta}

Sterile material of this species was collected in September 1970 and then fertile material was obtained in October and November: by December the taxon was absent. A few samples were found in the same location in September 1971.

The material agrees well with Korchikoff's illustrations reproduced in Bourrelly (1966, p. 173, Pl. XXVI, fig. 4a, b, c). This species occurs in Russia, Great Britain and France (Bourrelly, 1966) but this is the first record from Australia.

Voucher Specimens: Chapman's Property, "Koolamon", Braidwood, Southern Tablelands, New South Wales, Valerie May 2.ix.1970 (Herb. sheet C149), 8.x.1970 (Bottle C151), 1.xi.1970 (Herb. sheet C152), 2.ix.1971. Surface water of dam.

\section{Ceramium paniculatum Okamura Rhodophyta}

This species was common at Jervis Bay, N.S.W., in the following localities: Murray's Beach, Naval Station, and at Hare Bay. The material matches well that described and illustrated by Okamura (1921, p. 114, PI. CLXXIX, fig. 8-16). C. paniculatum is quite distinctive because of the 2-4-celled spines occurring at the nodes near the apices of the branches.

It is not known whether this Japanese species is a recent introduction to Australia, or whether it is in fact native to Australia bit not previously recorded.

Voucher Specimen: Hare Bay, Jervis Bay, New South Wales, Valerie May 29.xi.1973. On Posidonia australis. 


\section{NEW RECORDS FOR NEW SOUTH WALES}

\section{Anotrichium tenue (Agardh) Naegeli Rhodophyta}

This species was recorded previously as a species of Monospora (May, Bennett and Thompson, 1970), but can now be determined definitely on the basis of tetrasporic material. The specimens agree with the description of Griffithsia tenuis published by Okamura (1933) except that branching does not originate "always from the proximal and near the basal wall of the cells", but also arises from the distal end of the cell. Abbott (1946) describes this species as also having "persistent dichotomous branching".

The species is cosmopolitan in warm to subtropical waters. It has been recorded previously as Griffithsia thyrsigera (Thwait.) Grun., from Western Australia, Northern Territory and Norfolk Island, and Baldock (1976) recently has shown that G. tenuis Ag. should be known as Anotrichium tenue (Ag.) Naeg. The present appears to be the first definite record of $A$. tenue from New South Wales.

Voucher Specimens: Plantation Point, Jervis Bay, New South Wales, Valerie May 1.ix.1973, 6.v.1973, 4.vi.1973, 30.vii.1973 (tetrasporic).

\section{Spyridia dasyoides Sonder Rhodophyta}

This material accords with Harvey's illustration of his S. opposita (1860, Pl. CLVIII) and with other material from Victoria held at NSW. According to Womersley \& Cartledge (1975) the species should be known as S. dasyoides Sond.

This species is recorded from the western and southern shores of the Australian continent, east to Victoria and also from Tasmania, but this is the first record of $S$. dasyoides from New South Wales. Possibly the species has not been recorded from New South Wales previously, because it occurs at too deep a level for between-tide collecting.

Voucher Specimen: Green Point, Warrah Sanctuary, Broken Bay, New South Wales, A. W. D. Larkum, D. Baker \& A. R. H. Martin 17.xii.1972. Sublittoral, $6 \mathrm{~m}$ depth, collected from rock by diving.

\section{Oscillatoria erythraea (Ehrenberg) Kuetzing Cyanophyta}

Formerly recorded as Trichodesmium erythraeum Ehrenberg.

This member of the marine plankton forms obvious surface blooms in warm waters off the coast of Queensland and Western Australia, as well as in most tropical and subtropical waters, according to Drouet (1968). He suggests that it may be an ecophene of the more widely distributed Oscillatoria submembranacea Ardissons et Strafforello.

In 1972 a surface bloom of this species occurred in the coastal waters of New South Wales. It was observed initially in late October near Taree and Coffs Harbour and was evident off the coast of Sydney* (Palm Beach to Cronulla) in early December. During maximum development the bloom extended over an area of about 2.5 hectares but it had disappeared by 20.xii.1972. This is the first record of O. erythraea for New South Wales.

* Collected by a number of observers from the New South Wales State Fisheries, The Maritime Services Board of New South Wales, the Commonwealth Department of Customs and Excise, the Commonwealth Health Department and the New South Wales Water Police. 
The same species caused a red tide off the SW. coast of Western Australia at Easter 1972 (Smith, 1972).

Voucher Specimen: A 1007, 3-5 km NE. of Long Reef, Sydney, New South Wales, M. Cooper 12.1972.

\section{UNUSUAL OCCURRENCES OF CERTAIN ALGAE}

\section{Unusual Bloom of Ectocarpus Lyngbye Phaeophyta}

The great variation occurring in this genus was noted by May (1939) and studied in more detail by Ravanko (1970). The latter uses the term "Ectocarpus complex" to indicate an interrelated complex of morphological forms in the order Ectocarpales. This group of plants occurs seasonally in great quantities in estuarine waters of New South Wales.

The present record belongs to a form of the Ectocarpus complex which matches Giffordia mitchelliae (Harvey) Hamel, as recognized by Clayton (1974). This species formed a dense bloom, i.e. floating, unattached alga, extending from near Port Macquarie to south of Diamond Head. Such an ocean bloom does not seem to have been recorded here previously.

J. Keane (pers. comm. 1972) obtained the same species from the estuary of the Hastings River, where, he reports, this species was so prevalent that it formed "sedimentary, carbonaceous, estuarine deposits". 12.1970 .

Voucher Specimen: A 1001, $0.8 \mathrm{~km}$ E. of Port Macquarie, New South Wales, A. Catford

\section{Anacystis cyanea (Kuetzing) Drouet et Daily Cyanophyta}

Observations on this species have been published previously (May, 1970). The further collection cited here is from the Upper Hawkesbury River where this species was dispersed over an extensive area between Windsor and Wisemans Ferry. The alga occurred in small clumps up to $1.3 \mathrm{~cm}$ in diameter as an almost pure population but not as a full bloom. This collection is notable, being from the Coast Division of the State and from a freshwater river the level of which is affected by tidal action. Most other collections of this species have been from upland or inland dams and reservoirs with little water movement (May, 1970).

Voucher Specimen: A 1002, Hawkesbury River, near Windsor, New South Wales, Valerei May 1.1973.

\section{Nostoc sphaericum Vaucher ex Bornet et Flahault Cyanophyta}

This species was recorded from New South Wales and Victoria by Sonder (1880): further recent collections are recorded here.

Voucher Specimens: Surveyor Creek, Walcha Road, Northern Tablelands, New South Wales, Valerie May 12.1968. On rock in flowing river*. Also A 1004, same locality, Valerie May 1.1970.

* I am grateful to Dr Francis Drouet of the Academy of Natural Sciences, Philadelphia, U.S.A., for the identification of this specimen. 


\section{REFERENCES}

Abbott, I. A., 1946-The genus Griffithsia (Rhodophyceae) in Hawaii. Farlowia 2: 441-442. Pl. iii.

Baldock, R. N., 1976-The Griffithsiaeae group of the Ceramiaceae (Rhodophyta) and its southern Australian representatives. Austral. J. Bot. 24: 509-593.

Bourrelly, P., 1966-Les algues d'eau douce. Les algues vertes. Boubée \& Cie. Paris.

Clayton, Margaret, 1974- Studies on the development, life history and taxonomy of the Ectocarpales (Phaeophyta) in southern Australia. Austral. J. Bot.: 22: $743-813$.

Drouet, F., 1968-Revision of the classification of the Oscillatoriaceae. Acad. Nat. Sci. Philadelphia Monogr. 15.

Harvey, W. H., 1860-Phycologia australica 3, Pl. CLVIII. Reeve, London.

May, Valerie, 1939-Ectocarpus confervoides (Roth.) Le Jol., Proc. Linn. Soc. New South Wales 64: 537-554.

May, Valerie, 1970-A toxic alga in New South Wales and its distribution. Contr. New South Wales Natl. Herb. 4: 84-86.

May, Valerie, Bennett, I. and Thompson, T. E., 1970-Herbivore-algal relationships on a coastal rock platform (Cape Banks, N.S.W.). Oecologia 6: 1-14.

Okamura, K., 1921-Icones of Japanese algae 4: 114, Pl. CLXXIX, fig. 8-16. Tokyo.

Okamura, K., 1933-Icones of Japanese algae 7: 1, Pl. CCCII. Tokyo.

Ravanko, O., 1970-Morphological, developmental and taxonomic studies in the Ectocarpus complex (Phaeophyceae). Nova Hedwigia 20: 179-252.

Smith, G. G., 1972-A red tide of Trichodesmium in coastal waters of Western Australia. Western Australian Naturalist 12: 81-83.

Sonder, W., 1880-Algae. Suppl. in F. Mueller, Fragmenta Phytographiae Australiae 11: 106 .

Womersley, H. B. S., and Cartledge, S., 1975-The southern Australian species of Spyridia (Ceramiaceae: Rhodophyta). Trans. Roy. Soc. South Australia 99: 221-234. 